\title{
REVIEW
}

\section{Vascular mechanisms in acute unilateral peripheral vestibulopathy: a systematic review}

\author{
Meccanismi vascolari nella vestibolopatia periferica acuta unilaterale: \\ una revisione sistematica
}

\author{
João Simões ${ }^{1,2}$, Stephan Vlaminck¹, Raquel Seiça², Frederic Acke³ ${ }^{3}$ António Miguéis ${ }^{4}$ \\ ${ }^{1}$ Department of Otorhinolaryngology, Centre Hospitalier de Mouscron, Mouscron, Réseau Santé Louvain, Belgium; ${ }^{2}$ Faculty \\ of Medicine, University of Coimbra, Coimbra, Portugal; ${ }^{3}$ Department of Otorhinolaryngology, Ghent University Hospital, Ghent, \\ Belgium; ${ }^{4}$ University Clinic of Otorhinolaryngology, Faculty of Medicine, University of Coimbra, Coimbra, Portugal
}

\begin{abstract}
SUMMARY
Acute unilateral peripheral vestibulopathy (AUPVP) is a frequent cause of vestibular loss. Several aetiologies have been proposed, but the exact mechanism remains unknown. The aim of this study is a systematic analysis of the literature evaluating the vascular aetiology of AUPVP. A systematic literature search was performed in PubMed, Cochrane Library and Embase, including articles published from January $1^{\text {st }}, 2010$ to November $30^{\text {th }}, 2020$. Two reviewers independently selected articles investigating a link between AUPVP and vascular disease. The following information was extracted: year of publication, country, level of evidence, assessed vascular risk factors and number of patients. A total of 450 articles was obtained. Eleven articles were retained with $100 \%$ agreement between the two reviewers. In a pooled population of 805 patients, the main results were the higher neutrophil to lymphocyte ratio and higher prevalence of vascular risk factors among AUPVP patients. A meta-analysis was not performed because the studies were too heterogeneous in terms of methodology. Indirect arguments for vascular mechanisms in AUPVP were found. These findings indicate that larger prospective well-controlled studies are needed to clarify the vascular aetiology of AUPVP.
\end{abstract}

KEY WORDS: acute unilateral vestibulopathy, risk factors, vestibular neuritis, vascular, acute vertigo

\section{RIASSUNTO}

La vestibolopatia periferica unilaterale acuta $(A U P V P)$ è causa frequente di perdita della funzione vestibolare. Sono state proposte diverse eziologie, ma il meccanismo esatto rimane sconosciuto. Lo scopo di questo studio è condurre un'analisi sistematica della letteratura per valutare l'eziologia vascolare dell'AUPVP. Una ricerca sistematica della letteratura è stata eseguita mediante PubMed, Cochrane Library ed Embase, includendo articoli pubblicati dal 1 gennaio 2010 al 30 novembre 2020. Due revisori hanno selezionato in modo indipendente articoli che studiano un collegamento tra AUPVP e malattie vascolari. Sono state estratte le seguenti informazioni: anno di pubblicazione, paese, livello di evidenza, fattori di rischio vascolare valutati e numero di pazienti. In totale sono stati identificati 450 articoli. Tra questi sono stati considerati gli undici su cui vi era completo accordo fra i due revisori. In una popolazione aggregata di 805 pazienti, i risultati principali sono stati il più alto rapporto tra neutrofili e linfociti e la maggiore prevalenza di fattori di rischio vascolare tra i pazienti con AUPVP. Non è stata eseguita una meta-analisi perché gli studi erano troppo eterogenei per quanto riguarda la metodologia. Sono stati trovati argomenti indiretti per i meccanismi vascolari in AUPVP. Questi risultati indicano che sono necessari studi prospettici più ampi e ben controllati per chiarire l'eziologia vascolare in AUPVP.

PAROLE CHIAVE: vestibolopatia unilaterale acuta, fattori di rischio, neurite vestibolare, vascolare, vertigini acute
Received: March 6, 2021

Accepted: April 8, 2021

Correspondence

João Simões

Department of Otorhinolaryngology, Centre Hospitalier de Mouscron, Avenue de Fécamp 49, B-7700

Mouscron, Belgium

Tel. +32467065968

E-mail: jofsim@gmail.com

Funding

None.

Conflict of interest

The Authors declare no conflict of interest.

How to cite this article: Simões J, Vlaminck S, Seiça R, et al. Vascular mechanisms in acute unilateral peripheral vestibulopathy: a systematic review. Acta Otorhinolaryngol Ital 2021;41:401409. https://doi.org/10.14639/0392-100X-N1543

(C) Società Italiana di Otorinolaringoiatria e Chirurgia Cervico-Facciale

\section{c) (i) $(\$$}

This is an open access article distributed in accordance with the CC-BY-NC-ND (Creative Commons Attribution-NonCommercial-NoDerivatives 4.0 International) license. The article can be used by giving appropriate credit and mentioning the license, but only for non-commercial purposes and only in the original version. For further information: https:// creativecommons.org/licenses/by-nc-nd/4.0/deed.en 


\section{Introduction}

Acute unilateral peripheral vestibulopathy (AUPVP) is considered the third most common peripheral vestibular disorder after benign paroxysmal positional vertigo and Meniere's disease ${ }^{1,2}$. Several hypotheses have been proposed for the aetiology of AUPVP, but the exact mechanism remains unknown. Nowadays, the term AUPVP is preferred over "vestibular neuritis" because it is unclear whether it is always an inflammation that provokes the dysfunction ${ }^{3}$. However, until recently, the vast majority of the literature contains the term "vestibular neuritis" (VN). In this work, the term AUPVP will be used henceforth.

According to the literature, the most likely origin of AUPVP is viral, namely herpes simplex type 1 . This is supported by a genome wide association study showing a link between the disease and single nucleotide variants of the host factor for HSV1 replication ${ }^{4}$. However, other aetiologies have been suggested including thrombosis and an autoimmune inner ear reaction ${ }^{5}$.

The clinical picture varies according to the extent to which the vestibular end organs or their innervation are affected $^{6}$. The patient might present a spontaneous horizontal nystagmus beating away from the lesion side and caloric testing paralysis/paresis; a reduced gain in the video head impulse test (vHIT) supports the diagnosis ${ }^{3}$. Vestibularevoked myogenic potentials (VEMPs) are helpful to distinguish between involvement of the superior and inferior vestibular nerves ${ }^{7}$. Acute unilateral peripheral vestibulopathy appears to be more common in the superior vestibular labyrinth and its afferents, which could be explained by the longer and narrower path through its bony canal and also explains why the posterior semicircular canal and saccule are less affected ${ }^{8}$. A previous history of upper airway infection or concomitant findings of herpes infection strongly points towards a viral aetiology. However, not all patients fit this profile and other causes may be considered, namely a vascular aetiology. Actually, like the inner ear, the kidney, heart and eyes are supplied with an end artery and many of the diseases that affect these organs are, in fact, mediated by vascular events, a topic that consequently deserves further research in AUPVP ${ }^{9-11}$. Any disturbance in the cochleovestibular blood supply can provoke an insult in the fluid homeostasis and metabolic supply, and may be related to a variability of inner ear disorders, such as sudden deafness, autoimmunity, age-related hearing loss, AUPVP and Meniere's disease ${ }^{12}$.

The inner ear is supplied by the labyrinthine artery (LA), an end artery. Usually, the LA derives from the anterior inferior cerebellar artery (AICA) and gives two main branches, the common cochlear (CCA) and anterior vestibular (AVA) arteries. The CCA divides into the main cochlear artery and the vestibulocochlear artery, the latter forming the posterior vestibular and the cochlear artery. The apical three fourths of the cochlea are supplied by the main cochlear artery and the basal one by the cochlear ramus. The AVA supplies the utricle, superior part of the saccule and ampullae of the superior and lateral semicircular canals. In contrast, the posterior vestibular artery supplies the inferior part of the saccule and the ampulla of the posterior semicircular canal ${ }^{13}$. Thus, an overlap exists between inner ear vascular supply and inner ear innervation. Theoretically, a sudden interruption of the blood flow of the anterior vestibular artery could affect the same structures of a superior vestibular nerve inflammation, and the symptoms could be the same in the setting of an inflammatory or a vascular insult ${ }^{14}$. A longitudinal population-based cohort study of 1925 individuals concluded that smoking, central adiposity and poorly controlled diabetes mellitus predicted incident hearing impairment, which may suggest inner ear atherosclerotic events ${ }^{15}$. The labyrinth is also vulnerable to ischaemia, like the other organs mentioned above, because it requires highenergy metabolism ${ }^{13}$. By contrast, the retrocochlear acoustic nerve has an abundant collateral blood supply from the lateral medullary artery, arteries of the adjacent dura mater and petrous bone and the inferior lateral pontine artery ${ }^{13}$. Thus, the different parts of the inner ear may be more prone to ischaemia than the nerves considering the different patterns of vascular supply.

In this work, we performed a systematic review of the most recent evidence studying the links between AUPVP and vascular disease, exploring if AUPVP patients have a higher vascular risk than general population.

\section{Materials and methods}

\section{Identification and selection of studies}

A systematic review was performed in December 2020 using three electronic databases: 1) PubMed, 2) the Cochrane Library and 3) Embase. The search strategy is presented in Table I. Studies published in English between January $1^{\text {st }}$, 2010 and November $30^{\text {th }}, 2020$ were retrieved.

The term VN was used also considering that the majority of published studies regarding AUPVP use this nomenclature. The literature search, selection and analysis were independently performed by two researchers (JS and AM). The studies included in our review were eligible if they met the following inclusion criteria: 1) studies in Humans, 2) definition of AUPVP clearly stated, 3) studies investigating a link between AUPVP and vascular disease and 4) one of the following types of articles: prospective cohort studies of consecutive patients, case-control studies of consecutive 
Table I. Search strategy.

\begin{tabular}{ll}
\hline PubMed & (Vertigo[Other Term]) AND (risk factors[MeSH Terms]); (vertigo[Other Term]) AND (vascular[Other Term]]); (acute vestibular neuritis[MeSH \\
& Terms]) AND vascular; (acute vestibular neuritis[MeSH Terms]) AND (risk factors[MeSH Terms]); (dizziness[MeSH Terms]) AND (risk \\
& factors[MeSH Terms]); (dizziness[MeSH Terms]) AND (vascular[Other Term]) \\
Embase & ((acute unilateral peripheral vestibulopathy) OR (vestibular neuritis)) AND (risk factors) OR (vascular)) \\
Cochrane & (vestibular loss) OR (vestibular neuritis) OR (vestibular hypofunction)ti,ab, kw \\
\hline
\end{tabular}

patients, retrospective reviews of consecutive patients and selected case series (prospective or retrospective). Studies were excluded if they consisted of expert opinions, reviews, letters or comments, original studies with different themes of interest, experiments on animals or cadavers and in vitro studies. The article selection was performed according to the Primary Reporting Items for Systematic Reviews and Meta-analyses (PRISMA) Statement (Fig. 1) ${ }^{16}$. All the discrepancies between researchers were resolved by consensus. The following information of the included studies was recorded: author, year of publication, country of publication, level of evidence, number of patients with AUPVP and analysed cardiovascular risk factors (CVRFs). Other papers were used to contextualise and discuss the presented studies.

\section{Level of evidence}

The included articles were evaluated with a level of evidence based on the Oxford Centre for Evidence-Based Medicine ${ }^{17}$. Level 1a refers to a systematic review of randomised controlled trials, level $1 \mathrm{~b}$ to an individual RCT, level $2 \mathrm{a}$ to a systematic review of cohort studies, level $2 \mathrm{~b}$ to an individual cohort study/low-quality RCT, level 3a to a systematic review of case-control studies, level $3 b$ to an individual case-control study, level 4 to a case-series or poorquality cohort/case-control study, level 5 to a case report or expert opinion. An independent assessment was carried out by the two reviewers. In case of disagreement, a third reviewer was consulted and consensus was stablished.

\section{Results}

\section{General results}

A total of 450 records were identified in the initial search. After identifying relevant articles based on title or abstract, 190 papers were retained, of which 151 were removed after application of exclusion criteria and elimination of duplicates. Then, the full text was read to confirm the eligibility of the articles according to the inclusion criteria. Twentysix articles were further excluded. Two studies were eliminated due to absence of clear definition of AUPVP. Finally, 11 articles met all inclusion criteria. This selection process is presented in Figure 1. The final selection of studies had

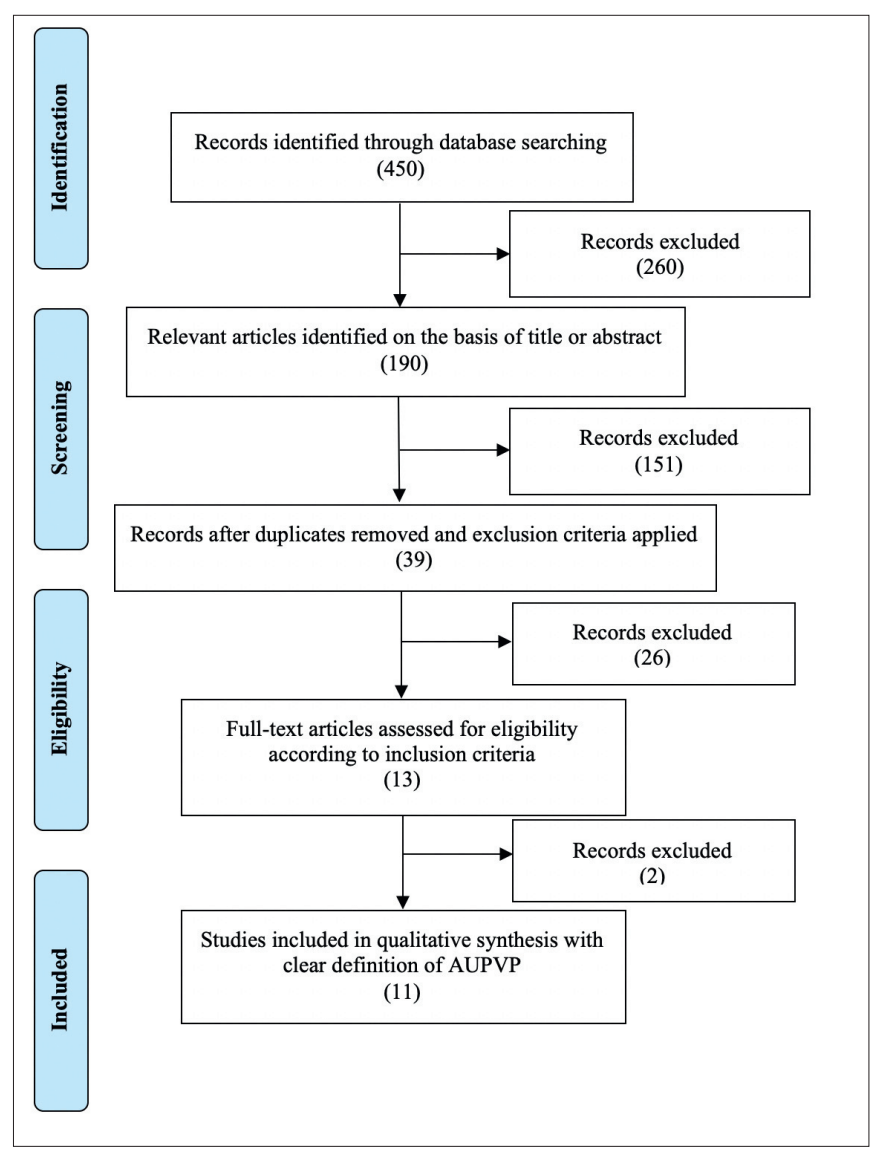

Figure 1. PRISMA flow diagram.

an interobserver agreement of $100 \%$. The heterogeneity of the selected studies and different methodologies made meta-analysis with pooled comparability impossible.

\section{Level of evidence}

Five studies were attributed with level $3 b$ of evidence and 6 studies with level 4 . The agreement between reviewers regarding the level of evidence was achieved for 9 studies. A third observer was needed to judge 2 studies and, after discussion, $100 \%$ of agreement was obtained.

\section{Study characteristics}

The total AUPVP population of the 11 studies was 805 adults aged 18-92 years. Nine studies had a gender-bal- 
anced population ${ }^{18-26}$. One study had a small number of females ${ }^{27}$ and another did not provide data regarding gender distribution ${ }^{28}$.

Details of the included articles are shown in Table II and III regarding included patients, nomenclature, measured outcomes and main results.

Studies investigating haemodynamic dysfunction in AUPVP One of the proposed mechanisms for acute vestibulopathy is embolic labyrinthine infarction. Labyrinthine infarction can be diagnosed only in association with other infarctions involving the brainstem or cerebellar areas supplied by the anterior inferior cerebellar artery, because current imaging techniques cannot visualise an infarction confined to the labyrinth ${ }^{27}$. Of 10 patients with acute audiovestibulopathy, 3 had isolated unilateral vestibulopathy. The embolic labyrinthine infarction was diagnosed based on the presence of cardiac or artery-to-artery sources of embolism and concurrent embolic infarctions observed in the non-AICA territories ${ }^{27}$. One patient had an atrial fibrillation, one an unknown patent foramen ovale and the other presented an occlusion of the vertebral artery. All 3 patients had concomitant infarctions on MRI, but only peripheral vestibular symptoms. None of the patients presented MRI findings in the involved labyrinth.

The vertebral artery hypoplasia (VAH) was also proposed

Table II. Summary of the definition of AUPVP (definition of cases) in each study included.

\begin{tabular}{|c|c|c|}
\hline First author / year & Definition of cases & Terms used \\
\hline Adamec I, $2015^{18}$ & $\begin{array}{l}\text { Vertigo attack lasting no more than } 48 \mathrm{~h} \text {, spontaneous horizontal-torsional } \\
\text { nystagmus with the fast phase towards one side, positive head-thrust test to the } \\
\text { other side and absence of skew deviation, a normal brain CT scan }\end{array}$ & Vestibular neuritis \\
\hline Chuang YM, $2011^{20}$ & $\begin{array}{l}\text { Acute onset of rotatory vertigo, nausea and postural imbalance; unilateral deficit } \\
\text { of the horizontal semi-circular canal and caloric irrigation showed }>25 \% \text { canal } \\
\text { paresis of the affected ear, a horizontal spontaneous nystagmus with a rotational } \\
\text { component towards the unaffected ear (fast phase) and the head-thrust test showed } \\
\text { an ipsilateral deficit of the horizontal canal, no tinnitus or acute hearing loss and } \\
\text { exclusion of central, bilateral or other peripheral vestibular dysfunction }\end{array}$ & Vestibular neuropathy \\
\hline Han W, $2018^{22}$ & $\begin{array}{l}\text { Strong vertigo attacks, vertigo attack no }>72 \text { h; spontaneous horizontal-torsional } \\
\text { nystagmus with the fast phase towards one side; obvious loss of vestibular function } \\
\text { as indicated by the video head impulse test; and absence of auditory complaints } \\
\text { and neurological symptoms or signs }\end{array}$ & Vestibular neuritis \\
\hline Liqun Z, $2018^{27}$ & $\begin{array}{l}\text { Acute peripheral vestibular syndrome with spontaneous horizontal-torsional } \\
\text { nystagmus beating toward the nonaffected side and vestibular deficit in VHIT or } \\
\text { caloric test }\end{array}$ & Unilateral peripheral vestibulopathy \\
\hline Navari E, $2019^{23}$ & $\begin{array}{l}\text { Long-lasting vertigo ( }>12 \mathrm{~h} \text { ) that was not attributed to other causes screened with } \\
\text { HINTS plus, vestibular deficit in VHIT, caloric test and VEMPS }\end{array}$ & Acute unilateral vestibulopathy \\
\hline Oh EH, $2020{ }^{24}$ & $\begin{array}{l}\text { Acute peripheral vestibular syndrome with spontaneous horizontal-torsional } \\
\text { nystagmus beating toward the nonaffected side and vestibular deficit in VHIT or } \\
\text { caloric test }\end{array}$ & Acute unilateral vestibulopathy \\
\hline
\end{tabular}


Table III. Overview of the study included.

\begin{tabular}{|c|c|c|c|c|c|c|c|c|}
\hline $\begin{array}{l}\text { First } \\
\text { author / } \\
\text { year }\end{array}$ & $\begin{array}{l}\text { Level of } \\
\text { Evidence }\end{array}$ & $\begin{array}{l}\text { Outcome } \\
\text { Measured }\end{array}$ & $\begin{array}{c}\text { No. of } \\
\text { patients }\end{array}$ & $\begin{array}{l}\text { Mean age of } \\
\text { patients } \\
\text { (years, range) }\end{array}$ & $\begin{array}{l}\text { Vascular risk } \\
\text { factor }\end{array}$ & Gender & Summary of results & Country \\
\hline $\begin{array}{l}\text { Adamec I, } \\
2015^{18}\end{array}$ & 4 & $\begin{array}{l}\text { AUPVP cases } \\
\text { in seasons; } \\
\text { vascular risk } \\
\text { factors }\end{array}$ & 79 & $52.3(20-86)$ & $\begin{array}{l}\text { Hypertension, } \\
\text { diabetes mellitus, } \\
\text { hyperlipidaemia }\end{array}$ & $\begin{array}{c}41 \text { male } \\
38 \text { female }\end{array}$ & $\begin{array}{c}\text { No evidence of seasonality of AUPVP. } \\
\text { Significant proportion of patients } \\
\text { older than } 50 \text { years who had } \\
\text { vascular risk factors }\end{array}$ & Croatia \\
\hline $\begin{array}{l}\text { Chuang YM, } \\
2011^{19}\end{array}$ & $3 b$ & $\begin{array}{l}\text { Vertebral artery } \\
\text { hypoplasia }\end{array}$ & 69 & $52.8(27-82)$ & $\begin{array}{l}\text { Haemodynamic } \\
\text { effect of the } \\
\text { vertebral artery } \\
\text { hypoplasia on } \\
\text { the vestibular } \\
\text { labyrinth }\end{array}$ & $\begin{array}{l}29 \text { male } \\
40 \text { female }\end{array}$ & $\begin{array}{l}\text { Vertebral artery hypoperfusion may } \\
\text { impede blood supply, contributing to } \\
\text { the development of AUPVP }\end{array}$ & China \\
\hline $\begin{array}{l}\text { Chuang YM, } \\
2011^{20}\end{array}$ & $3 b$ & $\begin{array}{l}\text { Vestibular } \\
\text { paresis }\end{array}$ & 69 & $52.8(27-82)$ & $\begin{array}{l}\text { Effect of vertebral } \\
\text { artery hypoplasia } \\
\text { on prognosis of } \\
\text { AUPVP }\end{array}$ & $\begin{array}{l}29 \text { male } \\
40 \text { female }\end{array}$ & $\begin{array}{l}\text { Comorbid vertebral artery } \\
\text { hypoperfusion may predispose to } \\
\text { severe AUPVP at acute stage }\end{array}$ & China \\
\hline $\begin{array}{l}\text { Chung JH, } \\
2017^{21}\end{array}$ & $3 b$ & Arterial stiffness & 58 & $53.8(N A)$ & $\begin{array}{l}\text { Arterial stiffness } \\
\text { and MetS }\end{array}$ & $\begin{array}{l}25 \text { male } \\
27 \text { female }\end{array}$ & $\begin{array}{c}\text { Arterial stiffness and higher } \\
\text { metabolic syndrome scores are } \\
\text { associated with the development of } \\
\text { AUPVP }\end{array}$ & Korea \\
\hline $\begin{array}{l}\text { Han W, } \\
2018^{22}\end{array}$ & $3 b$ & $\begin{array}{l}\text { Cerebrovascular } \\
\text { risk factors }\end{array}$ & 90 & $43.62(27-92)$ & $\begin{array}{l}\text { Age, hypertension, } \\
\text { diabetes mellitus, } \\
\text { lipids, carotid } \\
\text { plaques }\end{array}$ & $\begin{array}{l}44 \text { male } \\
46 \text { female }\end{array}$ & $\begin{array}{l}\text { Prevalence of carotid plaque was } \\
\text { significantly higher in AUPVP } \\
\text { patients than in healthy controls. No } \\
\text { differences regarding hypertension, } \\
\text { diabetes mellitus and lipids }\end{array}$ & China \\
\hline $\begin{array}{l}\text { Liqun Z, } \\
2018^{27}\end{array}$ & 4 & $\begin{array}{l}\text { Layrinthine } \\
\text { infarction }\end{array}$ & 10 & $57.2(38-76)$ & Embolic source & $\begin{array}{c}8 \text { male } \\
2 \text { female }\end{array}$ & $\begin{array}{l}\text { Three patients developed AUPVP } \\
\text { without evidence of auditory } \\
\text { involvement. Embolic sources should } \\
\text { be sought in patients with acute } \\
\text { audiovestibulopathy of unknown } \\
\text { aetiology }\end{array}$ & China \\
\hline $\begin{array}{l}\text { Navari E, } \\
2019^{23}\end{array}$ & 4 & $\begin{array}{l}\text { Recovery rate } \\
\text { and need of } \\
\text { rehabilitation }\end{array}$ & 59 & $\begin{array}{c}\text { Male } 54.06(24-77) \\
\text { Female } 58.31 \\
(23-81)\end{array}$ & Age & $\begin{array}{c}31 \text { male } \\
28 \text { female }\end{array}$ & $\begin{array}{l}\text { No effects of age in spontaneous } \\
\text { recovery and in need of vestibular } \\
\text { rehabilitation after AUPVP }\end{array}$ & Italy \\
\hline $\begin{array}{l}\text { Oh EH, } \\
2020^{24}\end{array}$ & $3 b$ & $\begin{array}{c}\text { Gene expression } \\
\text { NLR }\end{array}$ & $\begin{array}{l}10 \\
72\end{array}$ & $\begin{array}{c}60.2(40-84) \\
60.6(N A)\end{array}$ & Inflammation & $\begin{array}{l}6 \text { male } \\
4 \text { female } \\
39 \text { male } \\
33 \text { female }\end{array}$ & $\begin{array}{l}\text { The neutrophil-mediated immune } \\
\text { pathway may contribute to the } \\
\text { development of AUPVP by mediating } \\
\text { inflammatory and thrombotic } \\
\text { changes in the vestibular organ }\end{array}$ & Korea \\
\hline $\begin{array}{l}\text { Oron Y, } \\
2017{ }^{25}\end{array}$ & 4 & Vascular risk & 160 & $56.22(18-89)$ & $\begin{array}{l}\text { Dyslipidaemia, } \\
\text { obesity, diabetes } \\
\text { mellitus, } \\
\text { hypertension, } \\
\text { ischaemic heart } \\
\text { disease }\end{array}$ & $\begin{array}{l}64 \text { male } \\
96 \text { female }\end{array}$ & $\begin{array}{c}\text { A significantly higher prevalence } \\
\text { of vascular risk factors was found } \\
\text { among AUPVP hospitalised patients } \\
\text { in comparison to the general } \\
\text { population }\end{array}$ & Israel \\
\hline $\begin{array}{l}\text { Şahin Mİ, } \\
201926\end{array}$ & 4 & NLR and PLR & 104 & $44(18-71)$ & Inflammation & $\begin{array}{l}53 \text { male } \\
51 \text { female }\end{array}$ & $\begin{array}{l}\text { The elevations of NLR and PLR } \\
\text { support the role of inflammation } \\
\text { in AUPVP. The high level of mean } \\
\text { platelet volume indicates the } \\
\text { possible role of the vascular } \\
\text { thrombosis in the etiology of AUPVP }\end{array}$ & Turkey \\
\hline $\begin{array}{l}\text { Uffer DS, } \\
2016^{28}\end{array}$ & 4 & $\begin{array}{c}\text { Vestibular } \\
\text { lesions patterns }\end{array}$ & 25 & NA (18-80) & NA & NA & $\begin{array}{c}\text { The results do not support the } \\
\text { neuritis hypothesis since about } \\
3 / 4 \text { of the patients had an } \\
\text { intralabyrinthine lesion pattern } \\
\text { inconsistent with an isolated nerve } \\
\text { lesion }\end{array}$ & Switzerland \\
\hline
\end{tabular}


as a potential trigger of haemodynamic dysfunction in AUPVP patients. Chuang et al. compared $29 \mathrm{VAH}$ (right/ left: 23/6) in AUPVP subjects and six VAH in controls (right/left: 5/1). There was a high accordance rate between the side of VAH and AUPVP: $65.5 \%$ of the patients had an ipsilateral AUPVP, in which left VAH showed a higher accordance rate $(83.3 \%)$. VAH accordance showed higher risk $(81 \%)$ for AUPVP subjects with a vascular risk compared to those without $(25 \%){ }^{19}$. The authors suggested that VAH contributes as a risk factor for the development of ipsilateral AUPVP, and is enhanced by atherosclerotic risk factors. Of interest, the accordance rate of VAH and AUPVP was $81 \%$ in the vascular risk group compared to $28 \%$ in the non-vascular risk group. Comparing VAH presence as a prognostic factor, the same study group showed vestibular paresis to be higher (56.8\%) in AUPVP subjects with VAH $(\mathrm{n}=29)$ compared to AUPVP subjects $(\mathrm{n}=40)$ without VAH $(37.4 \%)(\mathrm{p}=0.01)$. The likely conclusion suggested comorbid VAH might predispose to AUPVP ${ }^{20}$. Moreover, the arterial stiffness has been proposed as a surrogate marker for vascular disease in AUPVP. In a prospective case-control study including 58 AUPVP patients versus 58 controls, arterial stiffness was measured by brachial-ankle pulse wave velocity ${ }^{21}$. Clearly, a higher brachial-ankle pulse wave velocity and higher prevalence of metabolic syndrome was observed in the AUPVP group compared to the control group $(\mathrm{p}=0.002$ and $\mathrm{p}=0.001$, respectively, Tab. IV). The authors concluded that these findings support the hypothesis of a vascular aetiology of AUPVP. However, cardiovascular risk factors had limited value in predicting the clinical course of AUPVP.

\section{Studies investigating inflammatory markers in AUPVP}

Neutrophil to lymphocyte ratio (NLR) and platelet to lymphocyte ratio (PLR) have been considered easily accessible inflammatory markers. Şahin et al. compared 104 AUPVP patients with 138 healthy subjects showing a significant higher NLR and PLR value in the AUPVP group $(\mathrm{p}<0.001$, Tab. IV), supporting the inflammatory role in AUPVP ${ }^{26}$. The same authors have also found an elevated mean platelet volume (MPV) in AUPVP patients proposing this finding as a risk marker for platelet activation, suggesting a vascular cause. Also, Oh et al. studied the inflammatory and thrombotic pathogenesis of acute unilateral vestibulopathy through gene expression profiling combined with bioinformatics analysis in 10 AUPVP patients and 10 controls ${ }^{24}$. They searched differentially expressed genes (DEGs) between these two groups. Interestingly, there were 57 DEGs (50 up-regulated and 7 down-regulated) identified in the patient's group and most of the up-regulated DEGs were significantly related to the neutrophil-mediated im- mune pathway. They completed the study with comparison of complete blood count tests in 72 patients and in agematched controls, showing that the NLR was significantly higher in the patients than in the controls (Tab. IV). Thus, they concluded that neutrophil-mediated immune pathway may contribute to the development of AUPVP by mediating inflammatory and thrombotic changes in the vestibular organ.

Studies investigating cardiovascular risk factors in AUPVP Based on a cross-sectional retrospective study of 160 confirmed VN patients, Oron et al. concluded that cardiovascular pathology and/or cardiovascular risk factors (hypertension, diabetes mellitus, dyslipidaemia, ischaemic heart disease and prior cerebral vascular accident/TIA) were significantly associated with AUPVP compared to the general population (Tab. IV) ${ }^{25}$. However, Han et al. did not found significant differences regarding hypertension, diabetes mellitus and dyslipidaemia between AUPVP patients and controls. Nevertheless, the prevalence of carotid plaques was significantly higher in AUPVP patients ${ }^{22}$.

In a prospective population-based study, 79 patients with recent AUPVP were followed in 2 different Croatian cities, for 2 years (2011-2012) with the evaluation of the impact of months, seasons and comorbidities ${ }^{18}$. No significant differences between months and seasons were detected. They observed that a significant proportion of AUPVP patients older than 50 years had vascular risk factors, namely, hypertension $(30.4 \%)$, diabetes mellitus $(8.9 \%)$, hyperlipidaemia $(7.5 \%)$ and hypothyreosis $(6.3 \%)$. Navari studied the results of caloric tests, VHIT and VEMPs in 59 patients with AUPVP ${ }^{23}$. They concluded that there was no effect of age regarding spontaneous recovery and vestibular rehabilitation. Moreover, they observed that most patients exhibited total end-organ damage, which could be related to damage of the entire labyrinth or, more probably, due to a neuritis of the two divisions of the vestibular nerve. Other studies also sought to analyse the vestibular lesion patterns and their connection with the distribution of the neurological afferents.

In the work of Uffer et al., the authors did not evaluate CVRFs, but they tested in what percentage of AUPVP patients the vestibular lesion pattern was observed at odds with the vestibular innervation anatomy ${ }^{28}$. Among the 25 patients, $19(76 \%)$ had a lesion pattern that looked more like an intra-labyrinthine pattern than a neuritis pattern. Half of the patients with a definite intra-labyrinthine pattern had major dysfunction differences in the receptors of the superior vestibular nerve, the other half had dysfunction differences in the receptors of the inferior vestibular nerve. The authors concluded that the results do not support 
Table IV. Main results of studies comparing cardiovascular risk factors and inflammation markers.

\begin{tabular}{|c|c|c|c|c|}
\hline Outcome & First author & Patients & Controls & $p$ \\
\hline \multirow{3}{*}{$\begin{array}{l}\text { Hypertension } \\
\text { (n) }\end{array}$} & Chung JH ${ }^{21}$ & 12 & 8 & 0.852 \\
\hline & $\operatorname{Oron} \mathrm{Y}^{25^{*}}$ & $42.5 \%$ & $11.2 \%$ & $<0.05$ \\
\hline & Han W 22 & 39 & 29 & 0.592 \\
\hline \multirow{3}{*}{$\begin{array}{l}\text { Diabetes Mellitus } \\
\text { (n) }\end{array}$} & Chung $\mathrm{JH}^{21}$ & 1 & 1 & 0.685 \\
\hline & Oron $Y^{25^{*}}$ & $15.62 \%$ & $6.6 \%$ & $<0.05$ \\
\hline & Han W 22 & 5 & 5 & 0.749 \\
\hline Dyslipidaemia & Oron $Y^{25^{*}}$ & $25 \%$ & $6.1 \%$ & 0.05 \\
\hline \multirow{2}{*}{$\begin{array}{l}\text { Cholesterol } \\
( \pm \text { SD) }\end{array}$} & Chung $\mathrm{JH}^{21}(\mathrm{mg} / \mathrm{dL})$ & $181.3 \pm 35.0$ & $176.4 \pm 37.0$ & 0.575 \\
\hline & Han W 22 (mmol/L) & $4.69 \pm 0.95$ & $4.73 \pm 0.87$ & 0.776 \\
\hline \multirow{2}{*}{$\begin{array}{l}\mathrm{TG} \\
( \pm \mathrm{SD})\end{array}$} & Chung $\mathrm{JH}^{21}(\mathrm{mg} / \mathrm{dL})$ & $118.2 \pm 90.4$ & $146.1 \pm 80.7$ & 0.111 \\
\hline & Han W 22 (mmol/L) & $1.48 \pm 0.96$ & $1.40 \pm 1.15$ & 0.661 \\
\hline \multirow{2}{*}{$\begin{array}{l}\mathrm{HDL} \\
( \pm \mathrm{SD})\end{array}$} & Chung $\mathrm{JH}^{21}(\mathrm{mg} / \mathrm{dL})$ & $49.76 \pm 13.8$ & $51.5 \pm 13.8$ & 0.507 \\
\hline & Han W 22 (mmol/L) & $1.45 \pm 0.56$ & $1.47 \pm 0.41$ & 0.700 \\
\hline \multirow{2}{*}{$\begin{array}{l}\mathrm{LDL} \\
( \pm \mathrm{SD})\end{array}$} & Chung $\mathrm{JH}^{21}(\mathrm{mg} / \mathrm{dL})$ & $112.1 \pm 32.2$ & $106.4 \pm 32.6$ & 0.352 \\
\hline & Han W 22 (mmol/L) & $2.57 \pm 0.86$ & $2.64 \pm 0.73$ & 0.577 \\
\hline $\begin{array}{l}\text { MetS Score } \\
( \pm \text { SD) }\end{array}$ & Chung $\mathrm{JH}^{21}$ & $1.5 \pm 1.2$ & $2.2 \pm 1.3$ & 0.001 \\
\hline \multirow[t]{2}{*}{ NLR } & Şahin Mİ ${ }^{26}$ (min-max) & $3.23(0.69-21.21)$ & $1.91(0.94-4.63)$ & $<0.001$ \\
\hline & Oh EH ${ }^{24}( \pm$ SD) & $2.93 \pm 2.25$ & $1.54 \pm 0.64$ & $<0.001$ \\
\hline \multirow[t]{2}{*}{ PLR } & Şahin Mi் 26 (min-max) & $145.65(37.83-696.15)$ & $128.29(39.63-259.85)$ & $<0.001$ \\
\hline & $\mathrm{Oh} E \mathrm{HH}^{24}( \pm \mathrm{SD})$ & $108.21 \pm 51.28$ & $125.37 \pm 33.98$ & 0.002 \\
\hline
\end{tabular}

MetS: metabolic syndrome; TG: triglycerides; LDL: low-density lipoprotein cholesterol; HDL: high-density lipoprotein cholesterol; NLR: neutrophil to lymphocyte ratio; PLR: platelet to lymphocyte ratio; SD: Standard Deviation; " Number (n) not available, control group is prevalence among general population.

the neuritis hypothesis since about three-fourths of patients had an intra-labyrinthine lesion pattern inconsistent with an isolated nerve lesion.

\section{Discussion}

The physiopathology of AUPVP needs further exploration concerning the role of viral inflammation and vascular events in the vestibular organ, with significant clinical implications. Acute vertigo may occur due to a labyrinth infarction, but current imaging techniques do not readily allow the identification of isolated labyrinthine infarctions as a cause of acute audiovestibulopathy ${ }^{13,27}$. This systematic review on the vascular mechanisms of AUPVP showed interesting findings. Our first is that comparison of results remains difficult due to the variety of terms used in different studies (Tab. II). Only recently, the literature has made the shift to the term of AUPVP ${ }^{3}$.

Furthermore, it is relevant to discuss the clinical signs in patients with an AICA stroke diagnosis showing isolated otovestibular dysfunction (vertigo, hearing loss and/or tinnitus) with normal MRI imaging one to 10 days before the appearance of neurological symptoms ${ }^{8}$. We may speculate that early symptoms might be caused by early smaller emboli deeper in the AICA vascular territory, namely the inner ear microcirculation. Supportive information are histopathology findings showing vascular occlusion in age-related hearing loss patients who are probably more prone to vascular accidents. Moreover, several cases of labyrinthine infarction have been linked to cardioembolism ${ }^{29-32}$ and isolated deafness have also been reported during embolisation of a meningioma ${ }^{33}$ or cardiopulmonary bypass surgery ${ }^{34}$. Moreover, artery-to-artery embolism is another mechanism of labyrinthine infarction ${ }^{35}$. Each compartment of the labyrinth may be selectively involved when embolism involves a specific branch of the LA causing isolated vertigo or hearing loss. For example, isolated vertigo may occur without hearing loss when the anterior vestibular artery is only involved, and hearing loss may be an isolated finding when the common cochlear artery is selectively affected ${ }^{27}$. Consequently, the clinical assessment of dizziness/vertigo patients, including accompanied neurological symptoms and signs, the presence of vascular risk factors and findings of ocular motor examination to detect stroke is likely to differentiate between central and peripheral aetiologies, but might also give an indication of the eventual origin of 
AUPVP aetiology. We should then attempt to detect MRI infarctions in other territories apart from AICA ${ }^{27}$.

Regarding NLR, interesting evidence points to a vascular origin of AUPVP. Oh et al. and Şahin et al. found NLR to be significantly higher in the AUPVP patients than in controls ${ }^{24,26}$. These findings suggest a neutrophil-mediated immune pathway in the development of AUPVP by mediating inflammatory and thrombotic changes in the vestibular organ. Indeed, viral infections usually induce an increase in the lymphocyte count and a decrease in the neutrophil counts, leading to lower NLR values ${ }^{36}$. Similar results were found in sudden sensorineural hearing loss (SSNHL) ${ }^{37,38}$. However, regarding MPV studies, Beyan and Beyan doubted this hypothesis with the argument that MPV-related research was hampered by the differences in MPV measurement standardisation leading to variable results ${ }^{39}$.

Aging, as a non-modifiable CVRF, showed no effect on spontaneous recovery and on need of vestibular rehabilitation ${ }^{23}$. In contrast, other CVRFs were significantly associated with AUPVP 25 .

Another argument for a distinctive pathogenetic mechanism in AUPVP is the comparison to Bell's palsy. Commonly, AUPVP is approached analogous to Bell's palsy, but important differences exist. First of all, corticosteroids have been found to be effective in the treatment of Bell's palsy, while their effect in AUPVP is less established ${ }^{40}$. This might suggest a different mechanism rather than a similarity. Then, benign paroxysmal positional vertigo (BPPV) is more prevalent in patients with a history of AUPVP (20\% of patients will develop BPPV in their lifetime ${ }^{41}$ ) which also supports a pathogenetic model with involvement of an intralabyrinthine lesion rather than a neuritis hypothesis ${ }^{28}$.

This review identified important gaps in the literature regarding the exploration of a vascular etiology in AUPVP. No cohort studies with a control group were found, in contrast to SSNHL studies ${ }^{42-45}$. Similarly, no studies were identified in this search regarding the risk of future vascular events (stroke and myocardial infarction) compared to the studies available for SSNHL ${ }^{46,47}$. Research on this topic is of paramount importance as it could help to clarify the possible presence of a higher vascular risk in AUPVP patients, with clinical relevance. The registration of clinical background and cardiovascular risk factors seems a simple and useful step in this matter. Adjunctive testing like VHIT and VEMPs may detect a specific lesion pattern for the 5 components of the vestibular system, which might be favourable for a neuritis hypothesis or for a vascular insult. When a high suspicion of vascular origin is present, cardiovascular assessment seems a reasonable approach.

\section{Limits of the studies and future directions}

There is some variation in the definition of AUPVP, which poses a challenge when trying to compare studies from different authors or clinics. Indirect arguments provided in recent literature sustain some evidence for vascular mechanisms. However, we realise that the majority of studies are retrospective in their analysis, with relatively small sample sizes, with limited data regarding the control group. Larger prospective studies of AUPVP patients could lead to a better diagnostic work-up and more precise therapy.

\section{References}

1 Neuhauser HK. The epidemiology of dizziness and vertigo. Handb Clin Neurol 2016;137:67-82. https://doi.org/10.1016/ B978-0-444-63437-5.00005-4

2 Muelleman T, Shew M, Subbarayan R, et al. Epidemiology of dizzy patient population in a neurotology clinic and predictors of peripheral etiology. Otol Neurotol 2017;38:870-875. https://doi.org/10.1097/ MAO.0000000000001429

3 Strupp M, Mandalà M, López-Escámez JA. Peripheral vestibular disorders: an update. Curr Opin Neurol 2019;32:165-173. https://doi. org/10.1097/WCO.0000000000000649

4 Rujescu D, Hartmann AM, Giegling I, et al. Genome-wide association study in vestibular neuritis: involvement of the host factor for HSV1 replication. Front Neurol 2018;20:591. https://doi.org/10.3389/ fneur.2018.00591

5 Jeong SH, Kim HJ, Kim JS. Vestibular neuritis. Semin Neurol 2013;33:185-194. https://doi.org/10.1055/s-0033-1354598

6 Hegemann SCA, Wenzel A. Diagnosis and treatment of vestibular neuritis/neuronitis or peripheral vestibulopathy (PVP)? Open questions and possible answers. Otol Neurotol 2017;38:626-631. https:// doi.org/10.1097/MAO.000000000000139

7 Fife TD, Colebatch JG, Kerber KA, et al. Practice guideline: cervical and ocular vestibular evoked myogenic potential testing: report of the Guideline Development, Dissemination, and Implementation Subcommittee of the American Academy of Neurology. Neurology 2017;89:2288-2296. https://doi.org/10.1212/ WNL.0000000000004690

8 Kim HA, Lee H. Recent advances in understanding audiovestibular loss of a vascular cause. J Stroke 2017;19:61-66. https://doi. org/10.5853/jos.2016.0085

9 Hilton R. Acute renal failure. BMJ 2006;333:786-790. https://doi. org/10.1136/bmj.38975.657639.AE

10 Kurmani S, Squire I. Acute heart failure: definition, classification and epidemiology. Curr Heart Fail Rep 2017;14:385-392. https://doi. org/10.1007/s11897-017-0351-y

11 Feroze KB, O'Rourke MC. Transient loss of vision. Treasure Island (FL): StatPearls Publishing 2020. https://www.ncbi.nlm.nih.gov/ books/NBK430845/

12 Mei X, Atturo F, Wadin K, et al. Human inner ear blood supply revisited: the Uppsala collection of temporal bone-an international resource of education and collaboration. Ups J Med Sci 2018;123:131-142. https://doi.org/10.1080/03009734.2018.1492654

13 Kim JS, Lee H. Inner ear dysfunction due to vertebrobasilar ischemic stroke. Semin Neurol 2009;29:534-540. https://doi. org/10.1055/s-0029-1241037 
14 Goebel JA, O'Mara W, Gianoli G. Anatomic considerations in vestibular neuritis. Otol Neurotol 2001;22:512-518. https://doi. org/10.1097/00129492-200107000-00018

15 Cruickshanks KJ, Nondahl DM, Dalton DS, et al. Smoking, central adiposity, and poor glycemic control increase risk of hearing impairment. J Am Geriatr Soc 2015;63:918-924. https://doi.org/10.1111/ jgs. 13401

16 Liberati A, Altman DG, Tetzlaff J, et al. The PRISMA statement for reporting systematic reviews and meta-analyses of studies that evaluate health care interventions: explanation and elaboration. J Clin Epidemiol 2009;62:e1-34. https://doi.org/10.1016/j.jclinepi.2009.06.006

17 Howick J. Oxford centre for evidence-based medicine: levels of medicine: Oxford centre for evidence-based medicine 2009. https://www. cebm.net/2009/06/oxford-centre-evidence-based-medicine-levelsevidence-march-2009/. Accessed Dec 2020.

18 Adamec I, Krbot SM, Handžić J, et al. Incidence, seasonality and comorbidity in vestibular neuritis. Neurol Sci 2015;36:91-95. https:// doi.org/10.1007/s10072-014-1912-4

19 Chuang YM, Chern CM, Liao WH, et al. Comorbid intracranial vertebral artery asymmetry as a risk factor for severe vestibular neuronitis. Otol Neurotol 2011;32:478-482. https://doi.org/10.1097/ MAO.0b013e 31820e785c

20 Chuang YM, Chern CM, Liao WH, et al. Contribution of intracranial vertebral artery asymmetry to vestibular neuropathy. J Neurol Neurosurg Psychiatry 2011;82:823-825. https://doi.org/10.1136/ jnnp.2009.203323

21 Chung JH, Lee SH, Park CW, et al. Clinical significance of arterial stiffness and metabolic syndrome scores in vestibular neuritis. Otol Neurotol 2017;38:737-741. https://doi.org/10.1097/ MAO.0000000000001352

22 Han W, Wang D, Wu Y, et al. Correlation between vestibular neuritis and cerebrovascular risk factors. Am J Otolaryngol 2018;39:751-753. https://doi.org/10.1016/j.amjoto.2018.08.006

23 Navari E, Casani AP. Lesion patterns and possible implications for recovery in acute unilateral vestibulopathy. Otol Neurotol 2020;41:e250e255. https://doi.org/10.1097/MAO.0000000000002476

24 Oh EH, Rhee JK, Shin JH, et al. Neutrophil-mediated immune response as a possible mechanism of acute unilateral vestibulopathy. J Vestib Res 2020;30:363-374. https://doi.org/10.3233/VES-200044

25 Oron Y, Shemesh S, Shushan S, et al. Cardiovascular risk factors among patients with vestibular neuritis. Ann Otol Rhinol Laryngol 2017;12:597-601. https://doi.org/10.1177/0003489417718846

26 Şahin Mİ, Kökoğlu K, Gülmez E. Mean platelet volume, neutrophil- and platelet to lymphocyte ratios are elevated in vestibular neuritis. J Clin Neurosci 2019;67:134-138. https://doi.org/10.1016/j. jocn.2019.05.062

27 Liqun Z, Park KH, Kim HJ, et al. Acute unilateral audiovestibulopathy due to embolic labyrinthine infarction. Front Neurol 2018;9:311. https://doi.org/10.3389/fneur.2018.00311

28 Uffer DS, Hegemann SC. About the pathophysiology of acute unilateral vestibular deficit - vestibular neuritis (VN) or peripheral vestibulopathy (PVP)? J Vestib Res 2016;26:311-317. https://doi. org/10.3233/VES-160581

29 Lee H, Kim JS, Chung EJ, et al. Infarction in the territory of anterior inferior cerebellar artery: spectrum of audiovestibular loss. Stroke 2009;40:3745-3751. https://doi.org/10.1161/ STROKEAHA.109.564682

30 Amarenco P, Rosengart A, DeWitt LD. Anterior inferior cerebellar artery territory infarcts. Mechanisms and clinical features. Arch Neurol 1993;50:154-161. https://doi.org/10.1001/ archneur.1993.00540020032014
31 Kumral E, Kisabay A, Ataç C. Lesion patterns and etiology of ischemia in the anterior inferior cerebellar artery territory involvement: a clinical - diffusion weighted - MRI study. Eur J Neurol 2006;13:395401. https://doi.org/10.1111/j.1468-1331.2006.01255.x

32 Amarenco P, Hauw JJ. Cerebellar infarction in the territory of the anterior and inferior cerebellar artery. A clinicopathological study of 20 cases. Brain 1990;113:139-155. https://doi.org/10.1093/ brain/113.1.139

33 Watanabe Y, Ohi H, Shojaku H, et al. Sudden deafness from vertebrobasilar artery disorder. Am J Otol 1994;15:423-426.

34 Wright JL, Saunders SH. Sudden deafness following cardio-pulmonary bypass surgery. J Laryngol Otol 1975;89:757-759. https://doi. org/10.1017/s0022215100080956

35 Raupp SF, Jellema K, Sluzewski M, et al. Sudden unilateral deafness due to a right vertebral artery dissection. Neurology 2004;27;62:1442. https://doi.org/10.1212/01.wnl.0000120757.35082.35

36 López-González MA, Abrante A, López-Lorente C, et al. Acutephase inflammatory response in idiopathic sudden deafness: pathogenic implications. Int J Otolaryngol 2012;216592. https://doi. org/10.1155/2012/216592

37 Koçak HE, Elbistanlı MS, Acıpayam H, et al. Are neutrophil/lymphocyte and platelet/lymphocyte ratios related with formation of sudden hearing loss and its prognosis? Eur Ann Otorhinolaryngol Head Neck Dis 2017;134:383-386. https://doi.org/10.1016/j.anorl.2016.06.005

38 Seo YJ, Park YA, Bong JP, et al. Predictive value of neutrophil to lymphocyte ratio in first-time and recurrent idiopathic sudden sensorineural hearing loss. Auris Nasus Larynx 2015;42:438-442. https://doi. org/10.1016/j.anl.2015.04.011

39 Beyan C, Beyan E. Mean platelet volume values may not be elevated in patients with vestibular neuritis. J Clin Neurosci 2019;70:269. https://doi.org/10.1016/j.jocn.2019.08.052

40 Fishman JM. Corticosteroids effective in idiopathic facial nerve palsy (Bell's palsy) but not necessarily in idiopathic acute vestibular dysfunction (vestibular neuritis). Laryngoscope 2011;121:2494-2495. https://doi.org/10.1002/lary.22327

41 Halmagyi GM. Diagnosis and management of vertigo. Clin Med (Lond) 2005;5:159-165. https://doi.org/10.7861/clinmedicine.5-2-159

42 Fasano T, Pertinhez TA, Tribi L, et al. Laboratory assessment of sudden sensorineural hearing loss: a case-control study. Laryngoscope 2017;127:2375-2381. https://doi.org/10.1002/lary.26514

43 Wang S, Ye Q, Pan Y. Serum non-high-density lipoprotein cholesterol is associated with the risk of sudden sensorineural hearing loss. Medicine (Baltimore) 2020;99:e19175. https://doi.org/10.1097/ MD.0000000000019175

44 Jalali MM, Nasimidoust Azgomi M. Metabolic syndrome components and sudden sensorineural hearing loss: a case-control study. Eur Arch Otorhinolaryngol 2020;277:1023-1029. https://doi.org/10.1007/ s00405-020-05808-z

45 Koo M, Hwang JH. Risk of sudden sensorineural hearing loss in patients with common preexisting sensorineural hearing impairment: a population-based study in Taiwan. PLoS One 2015;27;10:e0121190. https://doi.org/10.1371/journal.pone.0121190

46 Kim JY, Hong JY, Kim DK. Association of sudden sensorineural hearing loss with risk of cardiocerebrovascular disease: a study using data from the Korea National Health Insurance Service. JAMA Otolaryngol Head Neck Surg 2018;144:129-135. https://doi.org/10.1001/ jamaoto.2017.2569

47 Kim SY, Lim JS, Sim S, et al. Sudden sensorineural hearing loss predicts ischemic stroke: a longitudinal follow-up study. Otol Neurotol 2018;39:964-969. https://doi.org/10.1097/MAO.0000000000001902 